\title{
Elderly Parent Caring for an Adult with Down syndrome: A Case Study
}

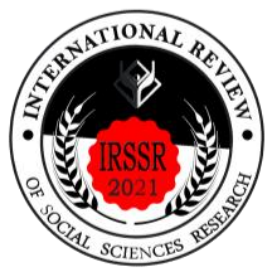

\section{Thessalonica M. Sinohin}

\begin{abstract}
The presence of mental and physical disabilities within the family members can be complicated to handle. A child with a mental disability has different demands than an adult with the same disability. However, an old-aged person raising an adult child with Down syndrome with occasional epileptic seizures is a whole different experience. Thus, the purpose of this case study is to examine the unique relationship, challenges, and demands of an elder parent caring for an adult child with a life-long mental illness. The family case gave many valuable insights into the challenges and struggles as a family under trial who find strength through faith, within themselves and among the circle of support, adapt and handle the stresses accompanying daughter's disability. The story also illustrated the hardships experienced by the father as the only caregiver of a mentally disabled daughter. Despite the difficulties experienced by the father, it was shown through the result of his Parental Stress Test that he is experiencing a low level of stress. His coping mechanism, such as his faith and perception in life and the support received from the people around him, made him positive and expectant of what the future may bring him and his daughter. It is recommended that the parents arrange legal assistance and financial plan as early as possible. The government should have supporting services that cater to the needs of the family's preparation for the future, such as free legal consultation, family budgeting workshops, and health insurance.
\end{abstract}

Keywords:

elderly parent, down syndrome, mental disability, parental stress

Suggested Citation: Sinohin, T.M. (2021). Elderly Parent Caring for an Adult with Down syndrome: A Case Study. International Review of Social Sciences Research, Volume 1, Issue 3, pp. $65-82$.

\footnotetext{
About the author:

Instructor I, Laguna State Polytechnic University- San Pablo City Campus
} 


\section{Introduction}

One of the common cases of mental illness is Down Syndrome (DS). It is generally caused by the presence of an extra chromosome 21 resulting in trisomy (Sherman et al., 2007). Trisomy 21 is the most common kind of Down syndrome. A typical person has 46 chromosomes, a person with DS has 47. This genetic disorder is characterized by developmental delays and physical features typical of the disorder (Grieco et al., 2015) which include weak information processing, social interaction, demonstrating language, receptive, and motor skills (Gandy et al., 2020).

The presence of mental and physical disabilities within the family members can be complicated to handle. Parents of children with mental disabilities take on the role of primary caregiver in the child's care (Juandó-Prats et al., 2021). Dealing and taking care of children with chronic illness, mental retardation and handicapped may bring painful experiences to the parents, as well as to the other members of the family. According to the family systems perspective, attributes of each family member influence the relationship, roles, and function of the family because all parts of the system are interconnected (White, Klein \& Martin, 2015). If one member of the system isn't functioning well, the whole system will struggle.

Studies showed that raising a child with a developmental disability, such as Down Syndrome, has fewer negative effects and more positive effects on the parents as caregivers. This is due to the parental acceptance and understanding of children's condition (Widyawati et al., 2021). However, an old-aged person raising an adult with Down syndrome and occasional epileptic seizures is a whole different experience. Thus, the purpose of this case study is to examine the unique relationship, challenges, and demands of an elder parent caring for an adult with a life-long mental illness. This study aimed to identify the difficulties

experienced by an elder parent of an adult with Down syndrome, understand the family's interaction pattern during the crisis, and examine the family's adaptability and coping strategies.

\section{Literature review}

\subsection{Theoretical Framework}

Family systems theory has been applied to understand the family under study. According to Keller and Noone (2019), family systems theory is used to better understand 
family relationship processes among family members. The theory stated that families are interconnected members of a system and individuals within the family are involvedly related to each other and that the events in one area of the system affect all other sections of the system. The connectedness of the family is a key concept of the family systems theory which asserts that all outcomes are the results of numerous causes. The family dynamics which include all types of communication within the family, family rules, family structure, and roles play significant roles within the system (Murray, 2006). This theory also focuses on the concept of holism which states that to understand an individual or a family, a person must look at the family as a whole (Keller \& Noone, 2019). From the perspective of family systems theory, the relational life of families provides the basic environmental setting in which children are raised. The traits that each family member bring to family relationship, as well as their opinions, have an impact on the family system. The presence of a child with a mental disability, such as Down syndrome, is likely to have a wide-range impact on the family system.

The presence of a disability is a family issue that can cause stress to the family. The severity of the disability determines the amount of stress of the family (Pang, 2010). However, a family under trial can cope and adapt to the present challenges through the unique interaction, unity, and interconnectedness of its members (Keller \& Noone, 2019). The family systems theory will provide a better perspective of the adaptability, coping strategy, struggles, and strengths of the family under study.

\subsection{Family Dynamics and Stress}

Some studies were conducted to see the dynamics going on in families of children with mental disabilities. It shows that children with intellectual disabilities have greater needs and have significant negative impacts and consequences on the family members (LimaRodríguez et al., 2017; Luijkx et al., 2017; Mulya et al., 2019). The stress level (emotional, physical, mental, and social) of parents and caregivers were commonly examined to understand the demand and the level of difficulty they experience. The level of difficulty is commonly associated with the severity of the disability and behavior problems (Boehm and Carter, 2019). 
Parents are usually experiencing increased stress levels which are related to the presence of disability in the family. Parents experience a high level of parental stress and health problems while responding to the difficulties and struggles related to raising a child with mental illness (Hou et al., 2018). Consequently, siblings of mentally disabled children also experience stress in the family setup. Adjustment in household activities is typical struggles. Moreover, siblings of children with mental disabilities turned out to have difficulties with their interpersonal relationships, managing leisure time, and school performance (Goudie et al. 2013).

Although several factors can contribute to the level of stress of caregivers and family members, the child's behavior problem often plays a major role in the stress (Luitwieler et al., 2021). Nevertheless, family as a system has its unique function of adaptability (Keller \& Noone, 2019) which creates resiliency during the time of stress. A positive coping strategy will likely decrease familial stress which has a positive effect on the child with mental illness (Sangawi et al., 2018).

\subsection{Children with Down syndrome}

A child with a mental disability has different demands from an adult with the same disability. As the individual grows, the demands increase, both on the parents and the individual. The condition of the child as he or she grows leads to parental adaptation which has been studied extensively about parental well-being. From adolescence to adulthood of a person with DS, parents experienced a wide range of challenges and stress as a result of their emotional response to the demands of their role (Cuskelly et al. 2009). In addition, parents of children with mental illness have common apprehensions regarding the future of their children. A study showed that adults with DS, aged 50 to 59, experienced more life events than other adults with mental illnesses. These life events include changes in daily routines, adjustment on living conditions, death of a parent, and medical problems (Desriyani et al., 2019). Inevitably, these life events will be faced not only by the parents but by the whole family. 


\section{Methodology}

\subsection{Research Design}

A qualitative, descriptive approach was adopted to explore the experiences and occurrences in the life of an elderly caring for an adult with mental disability. The study used a single-case design that focuses on a particular story or phenomenon. Single-case design is a strong procedure helpful to understand underlying relations (Nock et al., 2007), specifically among family experiences. Different sources of data were used in the study such as direct observation, in-depth interview, and questionnaire. The data obtained were systematically collected, analyzed, and presented in narrative form.

\subsection{Participants}

The participant of this case study is a family of two - a 79-year old father and his 44year-old youngest daughter with DS and epilepsy. The father works as a home-based hog raiser and is a retired plant nursery worker in Saudi Arabia. He worked abroad for 11 years and came back to the Philippines in 1997. His wife died due to complications of kidney failure. His other three daughters are living with their own families and his only son died in 1996. They lived in a small bungalow house near their relatives in the town of Masaya, Bay, Laguna, Philippines. The father started living alone with her mentally disabled daughter after her wife died in the year 2000.

\subsection{Instrument and Procedure}

The case study utilized three methods in gathering data - direct observation, nonstructured interview, and Parental Stress Scale Questionnaire (Berry \& Jones, 1995). Direct observation was done during the interview and the visits to the participant's residence. Observable data were taken using notes of what was seen, heard, and sensed in the area. The observations focused on human actions and the physical environment of the participant. On the other hand, the interview was recorded and conducted face-to-face. Open-ended questions were asked to reveal the reality of the participant's condition which provided significant insights into the case. Lastly, the Parental Stress Scale Questionnaire was used to measure the level of stress experienced by the parent at present. It is an 18 item self-report scale that shows the positive and negative aspects of parenthood (Berry \& Jones, 1995). It 
used a 5-point scale to represent strongly disagree, disagree, undecided, agree, and strongly agree to describe the kind of relationship the child has with the parent.

\subsection{Data Collection and Analysis}

The data preparation is the first step in the analysis of the case. The data from observational notes were examined thoroughly, while the data of voice recording obtained from the interview were transcribed verbatim. The combination of observational notes and transcribed recordings were linked together to get the whole picture of the story. Editing of the data took place during and after the initial write-up of the story. Moreover, the data from the Parental Stress Scale Questionnaire was computed based on the scoring procedure. Items $1,2,5,6,7,8,17$, and 18, which showed the positive aspect of parenting, were reversely scored. The scores from all the items were then summed. The total score of the Parental Stress Scale signifies the level of stress of the parent. A score of 18 indicates the lowest level of parental stress and a score of 90 indicates the highest level of parental stress (Berry \& Jones, 1995).

\section{Findings and Discussion}

The findings were divided into three sets: the family story and interaction, the challenges faced by the father as the only caregiver, and the adaptability and coping strategies of the family as well as the father alone.

\subsection{The Family Story and Interaction}

Using the perspective of family systems theory, one way to capture family dynamics over time is to look at how the family has dealt with stress or adapted to challenges. It can predict family interdependence and identify areas where family system flexibility can be increased (Keller \& Noone, 2019). The family consisted of a father, mother, four daughters, and a son. The first and second children were girls, followed by a boy, then another two girls. The father worked as a plant nursery worker in Saudi Arabia for 11 years. He consistently comes home every 2 years and in 1997 he came home for good. His wife was a public school teacher at Masaya Elementary School. Their first four children displayed the typical characteristics of a normal child. However, when their last child came, it was quite different. 
The family never knew that their youngest child has special needs until they observed something unusual.

(“Ang napansin naming sa kanya na kakaiba ay napakatahimik nya nung baby pa sya kesa nung baby pa yung iba naming anak. Di sya umiiyak masyado at wala din syang kiliti. Papalit-palit din kami ng gatas noon sa kanya pero parang wala syang magustuhan. Dahil napansin naming na kakaiba nga sya, nagpunta kami sa doctor nung mga tatlong taong gulang sya. Tinignan sya ng doctor at pinatest yung bata. Sinabi sa amin ng doctor na may Down Syndrome sya... Kwarenta na sya ngayon pero ang edad ng isip nya para lang walong taong gulang na bata.”)

"One of the distinct difference of our daughter among her siblings was she was a very quiet baby. She seldom cries and she also didn't respond to our tickle. We kept on changing her milk because we can't seem to find the milk she wanted. When my wife and I knew that maybe there was something wrong with her, we immediately went to the doctor. She was 3 years old when we had her checked. After some tests were done, she was diagnosed with Down syndrome. Today, she's already 40 years old but she thinks and acts like an eight-yearold child."

Raising their children wasn't a great challenge to the couple. Even with the condition of their youngest child, their growing years were normal. Her siblings loved her and were protective of her, especially her only brother. They easily accepted her condition primarily because their daughter was not a difficult child. They did not experienced tantrums or any forms of difficult behavior. According to Widyawati et al. (2021), acceptance of family members to the child's mental disability is vital to family resilience. Positive perception of parents leads to happiness and understanding in rearing their children which serves as a coping resource to them (Suzuki et al., 2015). As a result, the family cultivated a good relationship with each other as well as with their youngest daughter.

("Eh sa isang pamilya naman hindi nawawala ang mga problema, pero hindi sya naging prolema sa amin. Hindi sya pinagmumulan ng away sa kanilang magkakapatid. Sa loob ng bahay namin, madalas tahimik lang sya. Gustong-gusto nga din sya ng mga tao duon sa amin. Palabati sya sa 
mga tao at mahilig sya makipaglaro sa mga bata kaya gusto din ng mga bata sa kanya.")

"Although problems in the family are normal, we never had any problem with her when she was growing up. She was just quiet in the house. She was never a cause of any fight with her siblings. She also has a good relationship with our neighbors because she greeted them whenever she was outside. The children in our place loved her because she loves to play with the kids."

According to Cuskelly et al. (2009), the birth of a child with DS affects the family system in many ways. Family interactions were likely to change during the growing years of a child with a disability. Positive interactions among the family members can be developed only when immediate acceptance of the child's disability happened. Another factor that creates a positive interaction within the family was the acceptance of the social group of the family.

The family provided everything their child's special needs. They had her checked to the doctor regularly when she was growing. She had a nanny and was enrolled in a special school in San Pablo City. In these times the father wasn't involving much in her early years because of his work abroad. He only saw her every two years for a month. But when he decided to stay, he needed to learn how to relate to her daughter well. He also ventured into small businesses to have a continuous source of income for the increasing needs of her daughter. After their three other daughters got married and their only son died in an accident, he and his wife was the only one left to take care of their special daughter.

("Ang asawa ko talaga ang madalas kasama ng anak ko at sya din ang nag-aalaga sa kanya. Sya ang nagpapaligo, nagpapakain at nagpapatulog sa kanya. Tumutulong naman ako minsan pag wala akong trabaho. Kaya lang nung umabot sya ng mga 30 yearsl old nag-umpisa syang magseizure... Pinatignan namin sya at ang sabi sa amin epileptic daw ang anaknamin")

"My wife usually was the only tending to the needs of our daughter such as bathing her, preparing her meals, and sending her off to bed. I helped her sometimes whenever I'm 
free. When she approached her 30's, her seizure started. We had her checked and we knew that she had epilepsy."

During this time, the family experienced extreme difficulty. Their daughter was having seizures, his wife got critical because of a kidney problem and his small business was not running well. His wife needed to undergo dialysis thrice a week and grew very weak. The father hadn't much time to make a living because his time was consumed in the caregiving of his wife and daughter. The hardship of taking care of his mentally disabled daughter and his sick wife was the beginning of a crisis in their family. A crisis is defined as "the subjective reaction to a stressful life experience that compromises the individual's stability and ability to cope or function," (Roberts \& Ottens, 2005, p.331).

\subsection{Challenges Faced by the Father as Caregiver}

In the year 2000, the wife died and the father was left alone to take care of their daughter. The adjustment period was painful and frustrating at times. According to the father, many times he didn't know what and how to give care for his daughter. The task of bathing her daughter and helping her to sleep was a struggle since his wife was the primary caregiver back then.

("Kapag inaatake ang anak ko, hindi ko alam ang gagawin. Nagpapanic kasi ako at napapasigaw na lang. Ang asawa ko ang madalas nag-aalaga sa kanya, madalas akong wala dahil sa mga baboy naming. Natagalan talaga ako bago ko matutunan maging kalmado. Noon naawa ako sa sarili ko at anak ko kapag inaatake sya. Parang wala akong magawa eh. Pero natutunan ko rin naman kung paano ang gagawin kapag inaatake sya.. Para sa akin para ko ba syang partner sa buhay ko at syempre eh mahal ko ang anak ko.”)

"When my daughter had seizures, I didn't know what to do. I was in panic and I kept shouting. It was my wife who took care of her because I was usually out of the house to run our small business. It took time for me to learn to be calm. Before, I felt depressed and frustrated whenever I see her having seizures. I felt helpless. But when I finally learned how to take care of her, it was easy for me. She is now my partner in this journey and I love her." 
Parental adaptation was extensively studied about parental well-being and stress. The emotional response of the parent to the demands of the parenting role predicts the level of adjustment the parent had with the child's condition (Widyawati et al, 2021). In our case, the father realized that he needed to learn caregiving skills to support the needs of her daughter, such as giving first aid for seizure patients. His attitude toward her daughter's condition was motivated by love. He humbly learned how to comfortably give a bath to her daughter and assist her during her monthly period. Other daily concerns, such as preparing coffee, washing the dishes, and sweeping the floor, was able to do by his daughter. Their partnership had given him confidence that her daughter can survive even at times he is not at home. This kind of perspective gives him hope for his child in the future.

\section{Table 1}

Positive aspects experienced as a parent

\begin{tabular}{llc}
\hline & \multicolumn{1}{c}{ Indicators } & Level of Agreement \\
\hline 1 & I am happy in my role as a parent & Strongly Agree \\
2 & $\begin{array}{l}\text { There is little or nothing I wouldn't do for my child(ren) if } \\
\text { it was necessary. }\end{array}$ & Strongly Agree \\
5 & $\begin{array}{l}\text { I feel close to my child(ren). } \\
6\end{array}$ & I enjoy spending time with my child(ren). \\
7 & My child(ren) is an important source of affection for me. & Agree \\
8 & Having child(ren) gives me a more certain and optimistic & Strongly Agree \\
& $\begin{array}{l}\text { view for the future. } \\
17\end{array}$ & I am satisfied as a parent. \\
18 & I find my child(ren) enjoyable. & Strongly Agree \\
\hline
\end{tabular}

Table 1 shows the positive aspect experienced being a parent which he scored the highest. It supported his claims that he looked at his daughter as a partner and not a burden. He appreciates her, enjoys her company and he feels close to her. He is also hopeful for the future of his daughter. At present, it shows that the father is satisfied with his role as a parent. 


\section{Table 2}

Negative aspect experienced as a parent

\begin{tabular}{llc}
\hline \multicolumn{1}{c}{ Indicators } & \multicolumn{1}{c}{$\begin{array}{c}\text { Level of } \\
\text { Agreement }\end{array}$} \\
\cline { 2 - 3 } 3 & $\begin{array}{l}\text { Caring for my child/ren sometimes takes more time and energy } \\
\text { that I have to give. }\end{array}$ & Agree \\
4 & $\begin{array}{l}\text { I sometimes worry whether I am doing enough for my child/ren } \\
9\end{array}$ & The major source of stress in my life is my child(ren). \\
10 & Having child(ren) leaves little time and flexibility in my life. \\
11 & $\begin{array}{l}\text { Having child(ren) has been a financial burden. } \\
\text { It is difficult to balance different responsibilities because of my } \\
\text { child(ren). }\end{array}$ & Agree \\
13 & $\begin{array}{l}\text { The behavior of my child(ren) is often embarrassing or stressful } \\
\text { to me. }\end{array}$ & Disagree \\
14 & $\begin{array}{l}\text {. If I had it to do over again, I might decide not to have } \\
\text { child(ren). }\end{array}$ & Disagree \\
15 & $\begin{array}{l}\text { I feel overwhelmed by the responsibility of being a parent. } \\
16\end{array}$ & $\begin{array}{l}\text { Having child(ren) has meant having too few choices and too } \\
\text { little control over my life. }\end{array}$ \\
\hline
\end{tabular}

Table 2 shows the negative aspect experienced by the father. It shows that the father didn't look at her daughter as a source of stress and he didn't regret having her in his life. He also expressed that the continuous demands in taking care of her daughter made him feel that his efforts were sometimes not enough. And being the only caregiver to his child, he felt overwhelmed with the responsibility accompanied by having a child with DS.

According to the result of his Parental Stress Scale, the father got a total score of 39 points. The maximum score of 90 points signifies the highest level of parental stress, while the minimum score of 18 points signifies the lowest level of parental stress. The result showed that the father has a low level of parental stress at present.

Lastly, as a solo parent, another challenge he's facing, is his health. The related issues of growing older, such as declining health status and widowhood, make older parents susceptible to the stresses of caring for an adult with mental illness or disability (Belcher, 1988). Older parents have little energy both in making a living and tending to the needs of their mentally disabled children. As a result, the uncertainty of the child's future is often the dilemma of older parents. 
("Kapag umuuwi ang mga anak ko tuwing pasko at bagong taon, ibinibilin ko sya sa kanila. Ako'y mahina na at marami na bang nararamdaman sa katawan kaya alam kong hindi ko sya maalagaan ng matagal. Lagi bang masakit ang mga kasukasuhan ko at minsan nga eh hindi ako makabanong sa katre. Marami nga akong nararamdaman eh hindi ko naman makuhang magpatingin dahil mas priority ko ang kakainin naming dalawa. Ipinapanalangin ko na lang na pakalooban pa ako ng lakas ng Diyos dahil kailangan pa ako ng anak ko.”)

"Whenever my other children visit me every Christmas and New Year, I always tell them to prepare themselves to take care of their youngest sister. I am weak and I know I won't be able to take care of her for that very long. I usually experience back and joint pains. There were times that I cannot get up from my bed. I know I may have health issues but my priority is to make a living for both of us. I always pray to God for continuous strength because my daughter needs me."

\subsection{Adaptability and Coping Strategies}

The relationship among family members plays a fundamental role, not only to the emotional and social development of the child but as well as the emotional well-being of the family members. In our case, the family's acceptance of the condition of the daughter served as a strength of the family. Aydin and Yamac (2014) defined acceptance as "the warmth, affection, care, comfort, concern, nurturance, support, or simply the love that the child can experience from their parents and other caregivers." Family system theory states that family resilience is often strengthened with the presence of mental illness in the family (Keller \& Noone, 2019). It was felt by the daughter who in return showed the same kind of love to her family.

("Hindi naman kami nahirapan tanggapin ang kondisyon nya dahil unang-una bigay sya ng Panginoon sa amin.. Mapagmahal sya atnmalambing syang bata. Paborito sya ng mga kapatid nya dahil marunong din sya magpatawa minsan. Siya nga ang kasiyahan duon sa amin. Mahal na mahal sya ng mga kapatid nya gaya ng pagmamahal naming mag-asawa.") 
"We easily accepted her condition because we know that she's a gift from God. She is a very loving daughter in her ways. She makes her siblings laugh making her the joy of our family. My other children love her as much as we do."

Another positive source of strength for him and his whole family was their relentless faith in God. The father often stated in the interview that their strength comes from God alone. When the tough time comes, together as a family, they acknowledge the fact that God is in control of everything. They live their lives one day at a time, knowing that the promises of God are true in their lives. Their faith reflects the strength they have as a family, as well as an individual.

("Nung panahong naghihirap talaga kaming pamilya dahil sa sunodsunod na pangyayari, dasal lang talaga ang ginagawa namin. Lagi naman naming kasama ang Panginoon at hindi Niya kami bibiguin. Siya din naman ang nagpapalakas sa aming lahat at hindi Siya nagkukulang hanggang ngayon na dalawa na lang kami. Minsan, kapag pinanghihinaan ako ng loob nagdadasal na lang ako. Alam kong ang mga pagsubok sa amin ay nakakapagpalapit sa amin sa Kanya.")

"During the toughest times in our family, prayer is the only thing we hold on to. We know that in this journey, God is with us. He has never failed us. He continues to strengthen my family and provides for us until now. When doubt and fear come to my mind, I will immediately pray. I know that these trials we have are avenues for us to come closer to Him."

Several studies have shown that having a sense of self-reflection as well as a good support system and confidence to deal with challenges have been associated with resilience (Rutter, 2013). Social groups and relationships, such as the church, are recognized to play a major role in promoting long-term resilience in people with mental disorders. The father stated that when his wife died, he never felt alone. His bible study group, the church and the support he got from his community made him realize that he was not alone in his journey. The people around him, aside from his relatives, showed their love not only to him but to his daughter as well. The relationship in a support group is identified as a central influence of reliance and that resilience requires on-going growth and development within the environment of the current challenges (Suzuki et al., 2015). Families' positive adjustment to 
challenging life conditions is influenced by the support they received from their social groups.

("Nung namatay ang asawa ko, nagtaka ako na ang daming kapitbahay ang madalas dumalaw sa akin. Iniisip ko di naman sila nadalaw sa akin dati. Minsan nagdadala pa sila ng ulam, minsan naman nakikipagkwentuhan lang, misnsa naman nakikipaglaro pa sila sa anak ko. Hinahayaan lang nila ang mga anak nila na makipaglaro sa anak ko. Para na ngang day care sa dami ng bata. Kahit ba ganoon eh panatag naman ako dahil alam kong gusto nila ang anak ko.")

"When my wife died, I was surprised that many people in my neighborhood often visit our house. Those people that I thought never cared for us. They sometimes bring food or just make time to talk to me and sometimes even play with my daughter. They let their children play with my daughter making our house looks like a daycare sometimes. It makes me feel relieved to see that my neighbors care for my daughter.

The relationship in a support group is identified as a central influence of reliance and that resilience requires ongoing growth and development within the environment of the current challenges (Walsh, 2003). Families' positive adjustment to challenging life conditions is influenced by the support they received from their social groups.

\section{Conclusion}

Every parent wants his or her child to live a healthy and normal life as possible. Every parent aspires to bring up their family in the best way. However, the journey of a family can never be planned because familial problems are inevitable to happen. The case of the family gave a lot of valuable insights into the challenges and struggles they had as a family under trial. The family was able to find strength through their faith in God, within themselves and among the circle of support they had, to adapt and handle the stresses that accompanied the daughter's disability. The story also gave us a picture of the hardships experienced by the father as the only caregiver of her mentally disabled daughter. Despite the hardships experienced by the father, it was shown through the result of his Parental Stress Test that he is experiencing a low level of stress. His coping mechanism, such as his faith and 
perception in life, as well as the support he received from the people around him, made him positive and expectant of what the future may bring to him and his daughter.

Families of children with mental disabilities have their unique ways of coping and overcoming the trials in their families. Parents seem to do everything to provide a normal and satisfactory life for their children. In this study, the partnership of husband and wife, along with the support of their children, were seen as a significant factor in coping with their situation in their early years. However, the main factor that changes the family's perspective was their faith in God. The father, though later he was the only caregiver for her daughter, experienced low stress on their situation. His love for his daughter gave him joy and fulfillment in taking care of her needs even though he is already slow and weak. His security and assurance of what will happen to them in the future lie in his deep faith in God. Furthermore, the community that supports him includes the church, relatives, and neighbors. These groups provided him with unwavering encouragement which translate to him having so much confidence and hope even with life's uncertainties.

Parents of children with mental disabilities must be prepared physically, mentally, emotionally, and socially with all the demands and difficulties that come along with caregiving. Aside from financial support and health services, the government must have comprehensive programs that will assist these families. Community awareness and education, for example, will prevent prejudice and discrimination against mentally challenged children. It will create an understanding that the community is part of the social well-being of the children and it will help overcome the stigma among family members.

Proper planning for future care must also be taught to the parents as well as to the other members of the family. Legal assistance and financial plan must be arranged by the parents as early as possible. The government, then, should have supporting services that cater to the needs of the family's preparation for the future such as free legal consultation, family budgeting workshops, and health insurance. These programs will not only address the needs of the families of children with mental disabilities but also improve the parent's parenting and problem-solving skills. 


\section{References}

Aydın, A. \& Yamaç, A. (2014). The relations between the acceptance and child-rearing attitudes of parents of children with mental disabilities. Eurasian Journal of Educational Research, 54, 79-98.

Berry, JD, \& Jones, W,H, (1995) The Parental Stress Scale : initial psychometric evidence. Journal of Social and Personal Relationships, 12, 463 - 472.

Boehm, T.L., Carter, E.W. (2019) Family quality of life and its correlates among parents of children and adults with intellectual disability. Am. J. Intellect. Dev. Disabil. 124 (2), 99-115.

Cuskelly, M., Hauser-Cram, P. and Van Riper, M. (2009) Families of Children with Down Syndrome: What we know and what we need to know, Down Syndrome and Practice, Advance Online Publication, Vol. 12, pp. 105-113

Desriyani, Y., Nurhidayah, I., \& Adistie, F. (2019). Burden of parents in children with disability at Sekolah Luar Biasa Negeri Cileunyi. NurseLine Journal, 4(1), 21-30. https://doi.org/10.19184/nlj.v4i1.8696

Gandy, K. C., Castillo, H. A., Ouellette, L., Castillo, J., Lupo, P. J., Jacola, L. M., ... \& Gramatges, M. M. (2020). The relationship between chronic health conditions and cognitive deficits in children, adolescents, and young adults with down syndrome: A systematic review. PloS one, 15(9), e0239040.

Goudie, A., Havercamp, S., Jamieson, B., \& Sahr, T. (2013). Assessing functional impairment in siblings living with children with disability. Pediatrics, 132(2), e47683. doi: 10.1542/peds.2013-0644

Grieco, J., Pulsifer, M., Seligsohn, K., Skotko, B., \& Schwartz, A. (2015). Down syndrome: Cognitive and behavioral functioning across the lifespan. American Journal of Medical Genetics Part 6 (Seminar in Medical Genetics), 169C, 135-149. https://doi.org/10.1002/ajmg.c.31439

Hou, Y., Stewart, L., Iao, L., \& Wu, C. (2018). Parenting stress and depressive symptoms in Taiwanese mothers of young children with ASD spectrum disorder: Association with children's behavioral problems. Journal of Applied Research in Intellectual Disabilities, 31(6), 1113-1121.

Juandó-Prats, C., James, E., Bilder, D. A., McNair, L., Kenneally, N., Helfer, J., \& Rico, S. (2021). DRAVET ENGAGE. Parent caregivers of children with Dravet syndrome: Perspectives, needs, and opportunities for clinical research. Epilepsy \& Behavior, 122, 108198.

Keller, M. N., \& Noone, R. J. (Eds.). (2019). Handbook of Bowen Family Systems Theory and Research Methods: A Systems Model for Family Research. Routledge. 
Lima-Rodríguez, J.S., Baena-Ariza, M.T., Domínguez-Sanchez, I., Lima-Serrano, M., 2017. Intellectual disability in children and teenagers: influence on family and family health. Systematic review. Enfermiria Clin. 28 (2), 89-102.

Lott, I.T., Head, E., 2019. Dementia in Down syndrome: unique insights for Alzheimer disease research. Nat. Rev. Neurol. 15, 135-147. https://doi.org/10.1038/s41582018-0132-6

Luijkx, J., Van der Putten, A.A.J., Vlaskamp, C., 2017. Time use of parents raising children with severe or profound intellectual and multiple disabilities. Child Care Health Dev. 43 (4), 518-526.

Luitwieler, N., Luijkx, J., Salavati, M., Van der Schans, C.P., Van der Putten, A.J., Waninge, A. (2021) Variables related to the quality of life of families that have a child with severe to profound intellectual disabilities: A systematic review. Heliyon 7 (7) https://doi.org/10.1016/j.heliyon.2021.e07372

Mulya, A. P., Yani, D. I., \& Ropi, H. (2019). Quality of life school-age children with attention deficit hyperactivity disorder (ADHD) in SLB C Bandung. Asian Community Health Nursing Research, 1(1), 36-40.

Murray, C. E. (2006). Controversy, constraints, and context: Understanding family violence through family systems theory. The Family Journal, 14(3), 234-239.

Nock, M. K., Michel, B. D., \& Photos, B. I. (2007). Single-Case Research Designs. Corwin Professional development book publisher. https://us.corwin.com/sites/ default/files/upm-binaries/19353_Chapter_22.pdf

Pang, Y. (2010). Facilitating Family Involvement in Early Intervention to Preschool Transition. School Community Journal, 20(2), 183-198.

Roberts, A. R., \& Ottens, A. J. (2005). The seven-stage crisis intervention model: A road map to goal attainment, problem solving, and crisis resolution. Brief Treatment and Crisis Intervention, 5, 329-339.

Rutter, M. (2013). Annual research review: Resilience-clinical implications. Journal of child psychology and psychiatry, 54(4), 474-487.

Sangawi, H., Adams, J., \& Reissland, N. (2018). The impact of parenting styles on children developmental outcome: The role of academic self-concept as a mediator. International Journal of Psychology, 53(5), 379-387. https://doi.org/10.1002/ijop.12380

Sherman, S. L., Allen, E. G., Bean, L. H., \& Freeman, S. B. (2007). Epidemiology of Down syndrome. Mental Retardation and Developmental Disabilities Research Reviews, 13, 221-227. https://doi.org/10.1002/mrdd.20157. 
Suzuki, K., Kobayashi, T., Moriyama, K., Kaga, M., Hiratani, M., Watanabe, K., \& Inagaki, M. (2015). Development and evaluation of a parenting resilience elements questionnaire (PREQ) measuring resiliency in rearing children with developmental disorders. PloS One, 10(12), Article e0143946. https://doi.org/10.1371/ journal.pone.0143946

Walsh, F. (2003). Family resilience: A framework for clinical practice. Family process, 42(1), 1-18.

White, J.M., Klein, D.M. and Martin, T.F. (2015). Family Theories: An Introduction, Fourth Edition, Sage Publication Incorporated

Widyawati, Y., Scholte, R. H. J., Kleemans, T., \& Otten, R. (2021). Positive parenting and its mediating role in the relationship between parental resilience and quality of life in children with developmental disabilities in Java Island, Indonesia. Research in Developmental Disabilities, 112, 103911. 